\title{
Mycosis Fungoides and Sezary Syndrome Peripheral Blood Involvement TNM
} Finding $v 7$

National Cancer Institute

\section{Source}

National Cancer Institute. Mycosis Fungoides and Sezary Syndrome Peripheral Blood

Involvement TNM Finding v7. NCI Thesaurus. Code C88249.

A finding about one or more characteristics of mycosis fung oides and Sezary syndrome, following the rules of the TNM AJCC V7 classification system as they pertain to peripheral blood involvement. (from AJCC 7th Ed.) 